\title{
Original Article \\ Role of Laws to Control Brick Manufacturing and Kiln Establishment in Bangladesh: Scope of Alternative Bricks
}

\author{
Akhter Hossain Sarker ${ }^{1}$, Asif Hossain Abir ${ }^{2, *}$ \\ ${ }^{I}$ Senior Research Officer, Housing and Building Research Institute (HBRI), \\ 120/3, Darussalam, Mirpur, Dhaka-1216, Bangladesh \\ ${ }^{2}$ Research Associate, Promoting Sustainable Building in Bangladesh Project, \\ Bangladesh Environmental Lawyers Association (BELA), \\ House no. 15/A, Road no. 3, Dhanmondi R/A, Dhaka-1205, Bangladesh
}

Received 11 March 2019

Revised 15 March 2019; Accepted 15 March 2019

\begin{abstract}
In Bangladesh, clay bricks are extensively used as building construction material. Rapid urbanization in the country has spurred the brick production of 8.6 billion each year. The larger part of brick fields has been set up illicitly, near human homes, schools, colleges, medicinal services offices, disregarding the current laws in this regard. Top soil of agricultural land is collected for producing bricks. As a result, our country is losing hectares of precious topsoil each year. In Bangladesh, around 12,000 brick kilns are in operation. A kiln produces averagely 8,500 bricks using 1,000 cubic feet of topsoil. Tons of forest wood is burned to produce bricks every year. Brick kilns emissions consist of carbon-dioxide $\left(\mathrm{CO}_{2}\right)$, particulate matter (PM) including black carbon $(\mathrm{BC})$, sulfur-dioxide $\left(\mathrm{SO}_{2}\right)$, oxides of nitrogen $\left(\mathrm{NO}_{\mathrm{x}}\right)$, and carbon monoxide $(\mathrm{CO})$, thereby causing air pollution. Brick kilns around Dhaka are responsible for up to 58 percent of all the fine-particulate air pollution in the capital.

The qualitative research approach was followed in order to explore the scope of Alternative Bricks (ABs) and also the role of law to control brick manufacturing and kiln establishment in Bangladesh. This study indicates that the law enforcement mechanism is not functioning properly as well as there are lots of loopholes in the existing laws to prevent the production of harmful clay bricks and promote Alternative Bricks (ABs).
\end{abstract}

Keywords:_Alternative bricks, brick kiln, clay bricks, law.

\section{Introduction}

Bangladesh is a developing country having dense population in comparatively small live-

\footnotetext{
* Corresponding author.

E-mail address: asifhossain49@iut-dhaka.edu
}

https://doi.org/10.25073/2588-1094/vnuees.4371 able land area. The population growth is comparatively high, causing increasing demand on development of built environment. Clay brick is the main and large consumable item of this built environment. Bangladesh, whose economy is primarily dependent on agriculture, is truly a land hungry country. The agricultural land is shrinking fast [1], both in quantity and 
quality, for development of built environment. One of the major reasons for qualitative degradation of agricultural land is that the top soil of cultivatable land is being used as the only source of material for manufacturing clay bricks [2]. The fast growing development of built environment is increasing the demand of clay bricks which is again inviting growth of new brick kilns causing pollution of environment and degradation of public health [3]. For this reason, searching for alternative options of clay bricks has become need of the times. Some entrepreneurs came with alternative bricks [4] but those bricks could not sustain in the market. So, Introduction of alternative bricks, commonly used or new, need thread bear research on its acceptability and sustainability as well. Introducing new system or options needs reviewing of existing rules and regulations in this regard. Any short fall or gap in acts, rules or regulations invite promulgation of new ones not conflicting the existing other related acts or rules. Owing to rapid industrialization, urbanization and increasing need of building structures, mostly dependent on clay bricks for their construction, brickmaking has become one of the fastest growing industries in Bangladesh, which worth about USD 10.3 million per year [5]. In this study an in depth research has been carried out to find out the sustainable alternative options of clay bricks, using alternative materials, through finding the supporting rules and regulations and identifying the barriers in adopting or reintroducing alternative bricks.

\section{Literature Review}

Clay bricks are found to be mass-produced and thoroughly tested modular building components which is affordable in price and readily available across the country. These clay bricks possess fantastic acoustic and thermal properties derived from their relatively high mass [6]. They require comparatively little maintenance and possess high durability and load bearing capacity [7]. According to a report titled "Specifications for and Classification of Brick" of Brick Industry Association (BIA), "Clay is generally composed of silica and alumina with varying amounts of metallic oxides. Metallic oxides act as fluxes promoting fusion of the particles at lower temperatures. Metallic oxides (particularly those of iron, magnesium and calcium) influence the colour of the fired brick" [8]. In Bangladesh top soil of agricultural land, riversides are found suitable for this purpose and even the soils of small hills, river banks or beds are found acceptable. The use of large quantities of coal in brick kilns contributes significantly to emission of carbon dioxide $\left(\mathrm{CO}_{2}\right)$, particulate matter $(\mathrm{PM})$, including black carbon (BC), sulphur-dioxide $\left(\mathrm{SO}_{2}\right)$, oxides of nitrogen $(\mathrm{NOx})$, and carbon monoxide (CO) [9]. The pollutants, not only have adverse effect to the health of workers, local population, and vegetation, but also contribute to global warming. To protect the environment and public health, the pollutant emission must be limited and be controlled. So, emission standards for brick kilns have been enforced by Ministry of Environment and Forest (MoEF), as shown in Table 1 [10].

As the brick kilns of various technologies use different methodology of firing and fuel as well, their emission quality also differs with respect to its pollution potentials. The emission quality of various brick kilns has been tabulated in Figure 1 [11].

To control the antagonistic effect of brick kilns, 'The Brick Manufacturing and Brick Kilns Establishment (Control) Act 2013'was introduced by the Government of Bangladesh [12]. It is considered as the mother law of country to control brick manufacturing and brick kiln establishment. 
Table 1. Emission standards for brick kilns by MoEF

\begin{tabular}{lll}
\hline Sl.no & Technology and size & $\begin{array}{l}\text { SPM (Suspended } \\
\text { Particulate } \\
\text { Matter)emission } \\
\text { standard }\end{array}$ \\
\hline 1 & $\begin{array}{l}\text { Fixed Chimney Bull's Trench Kiln (FCBTK); Large and medium size } \\
\text { (capacity }>15,000 \text { bricks/day) }\end{array}$ & $<750 \mathrm{mg} / \mathrm{Nm}^{3}$ \\
2 & Small size (capacity $<15,000$ bricks/day) & $<1,000 \mathrm{mg} / \mathrm{Nm}^{3}$ \\
3 & Vertical Shaft Brick Kiln (VSBK) & $<250 \mathrm{mg} / \mathrm{Nm}^{3}$ \\
4 & Down-draft kiln & $<1,200 \mathrm{mg} / \mathrm{Nm}^{3}$ \\
\hline
\end{tabular}

Source: Ministry of Environment and Forests, The Gazette of India, Part II, Section 3, Sub-section (i), 22 July 2009.

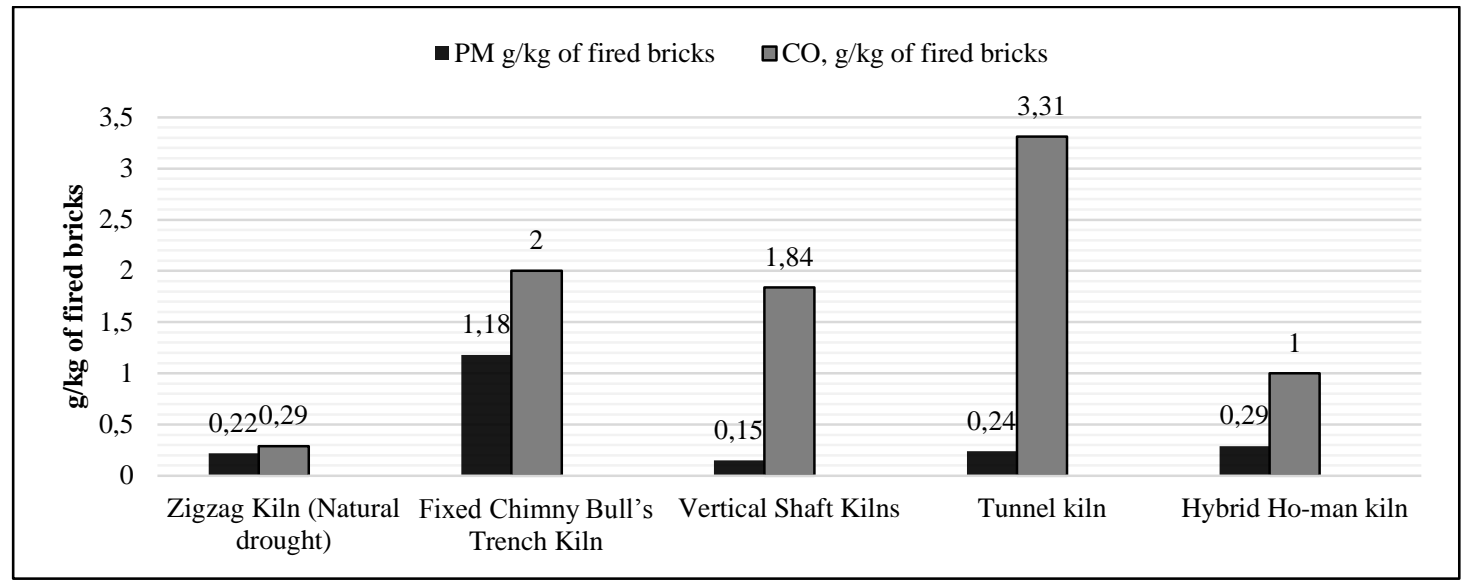

Fig. 1. Emission quality of various brick kilns.

Some important provisions of the act are:

- Brick production has been precluded without having a license from the Deputy Commissioner (DC) of the district where the kiln will be established.

- No license will be needed for producing concrete blocks.

- It is restricted that no individual will utilize the soil as crude material in brick production in the wake of cutting or gathering it from rural land or slope or hillock, without the endorsement of authority, no individual will cut or gather soil with the end goal of brick production from dead lake or trench or marsh land or stream or profound tank or waterways or scorch land or decrepit land.

- Minimum 50 (fifty) percent Hollow Brick should be produced in the brick kilns.
- Using forest woods and coal as fuel has been restricted.

- No individual will be permitted to utilize coal, as fuel, containing sulfur, mercury or comparative material, past the endorsed standard.

- No individual will be permitted to build up block furnace inside the limits of the accompanying territories, to be specific: (a) Private, saved or business zone; (b) City Organization, District base camp; (c) Open or exclusive backwoods, asylum, patio nurseries or wetlands; (d) Farming area; (e) Naturally Basic Region; (e) Corrupted Air Shed.

- On the off chance that any individual disregards the states of permit or perpetrates any wrongdoing culpable under this Demonstration, the Representative Officials may give a request 
in endorsed way and conditions, to suspend the enforceability of permit of such individual.

There are various types of bricks made by different materials other than clay. Many of those are widely being used in building development sector, globally. Among those alternative bricks cement-sand block is very popular and are being used in many parts of the globe.

Concrete bricks: Concrete bricks are made by pressing the mixture made by sand (coarse and fine) and cement, adding some water [13]. No burning is required, only curing is needed for completing reaction with cement for gaining strength. Concrete blocks are mainly hollow blocks though solid concrete blocks are also available. The standard size of a concrete hollow block is $390 \mathrm{~mm}$ long, $190 \mathrm{~mm}$ high and width of varying sizes like $140 \mathrm{~mm}, 190 \mathrm{~mm}$ (standard) and $240 \mathrm{~mm}$. Blocks are made by pressing cement and sand mixture in a mould. As the mould is hollow it reduce weight. They have great thermal conductivity. These are increasingly used in construction, worldwide.

Aerated concrete bricks: Aerated concrete bricks are made from quartz sand, calcined gypsum, lime, cement, water and aluminum powder [14]. Aeration process is done by generating hydrogen gas within the mixture. Mixing of sand and cement is carried out by adding certain amount of water which is continued for the introduction of foam by generating gas bubbles, in order to ensure good distribution of the air cells throughout the mixture. The slurry of mixtures are then cast in iron molds. Molds can be of various sizes depending upon installed capacity like $4.2 \mathrm{~m} \mathrm{x}$ $1.2 \mathrm{~m} \times 0.65 \mathrm{~m}$ in size. While slurry is mixed and poured into greased molds,

Aluminum reacts with Calcium Hydroxide and water and releases hydrogen gas. This leads to formation of tiny cells causing slurry mix to expand. Such expansion may be thrice its original volume. Bubble size is about 2$5 \mathrm{~mm}$.Thus, this is the reason behind light weight and insulating properties of AAC block.
When rising process is over, the mixture is allowed to settle \& cure. Once it achieve cutting strength, it is ready to be demolded and cut as per requirements.

Non-fired bricks: Sand Lime Bricks: Sand lime bricks are also termed as Calcium Silicate Bricks. These bricks are made from the mixture of fly ash, sand and lime, by molded under pressure. Bhangale [15] described some precedence of these bricks:

\section{Change of looks (in color)}

2. Less mortar needs in plastering.

3. Gives moderate compressive strength.

\section{Methodology and data}

This paper followed qualitative research approach in order to explore the scope of Alternative Bricks (ABs) in Bangladesh and also role of law to control brick manufacturing and kiln establishment in Bangladesh. In doing so, it has taken both primary and secondary data into account. The primary source materials are the documents/reports available in the public domain and scientific research works done by Housing and Building Research Institute (HBRI). A plethora of germane material available in different ministries of Government of Bangladesh (GoB) has also been reviewed. While conducting the research, maximum use of online sources has been done. Interviews with experts and scholars working on regional connectivity have also been incorporated to supplement the documentary source material and add value to the research output. Similarly, interaction has also been carried out with the officials from neighboring countries to incorporate their perspective.

\subsection{Impacts on air}

In brick manufacturing industry about 2.2 million tons of coal and 1.9 million tons of wood is burned every year which results in emission of 8.75 million tons of greenhouse gas $\left(\mathrm{CO}_{\mathrm{x}}, \mathrm{NO}_{\mathrm{x}}, \mathrm{SO}_{\mathrm{x}}\right.$, etc. $)$ annually [16]. Average 
emission factors per 1,000 bricks are 0.52-5.9 $\mathrm{kg}$ of sulphur-di-oxide. Other endangering gases are carbon monoxide and fluorine. Air pollution worsens from end of October and continues until the rainfall starts. It is being experienced that during the dry seasons, Dhaka is one of the most polluted cities in the world [17]. According to Bangladesh standards [18], the permissible level of 24 hour average particulate matters $\mathrm{PM}_{10}$ in the city air is 150 microgram per cubic meter $\left(\mu \mathrm{g} / \mathrm{m}^{3}\right)$. But the study conducted by AQMP shows that, in Dhaka during the month of November, the $\mathrm{PM}_{10}$ rose to 230 microgram per cubic meter [18]. The $\mathrm{PM}_{2.5}$ in Dhaka reached to 160 microgram per cubic meter while the endurable air quality is that having 24 hour average $\mathrm{PM}_{2.5}$ $65\left(\mu \mathrm{g} / \mathrm{m}^{3}\right)[18]$. A public notice served by DoE in December 2016 [19], reveals that $58 \%$ of the particulate pollutants responsible for the smog in the air of Dhaka city comes from the unorthodox brick kilns around and inside Dhaka. According to a study [20], an estimated 15,000 premature deaths annually, as well as several million cases of pulmonary, respiratory and neurological illness are attributed to poor air quality in the capital city [20]. Figure 2 shows the average annual $\mathrm{PM}_{2.5}$ concentration of Dhaka city of last 20 years [21].

Due to rapid growth of brick kilns the air pollution rate is also increasing [22-25]. Figure 3 shows the growth of brick sector of Bangladesh over past ten years.

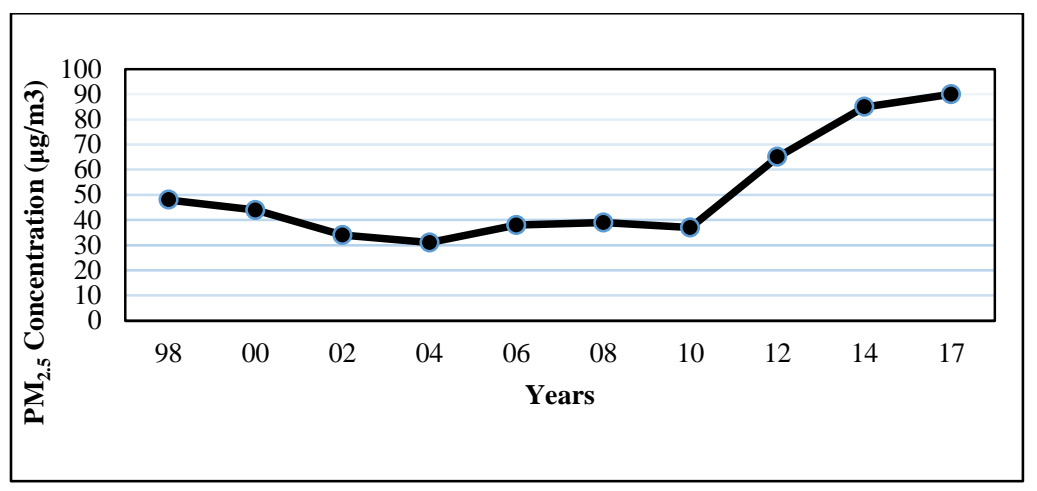

Fig 2. Average annual $\mathrm{PM}_{2.5}$ concentration of Dhaka city of last 20 years.

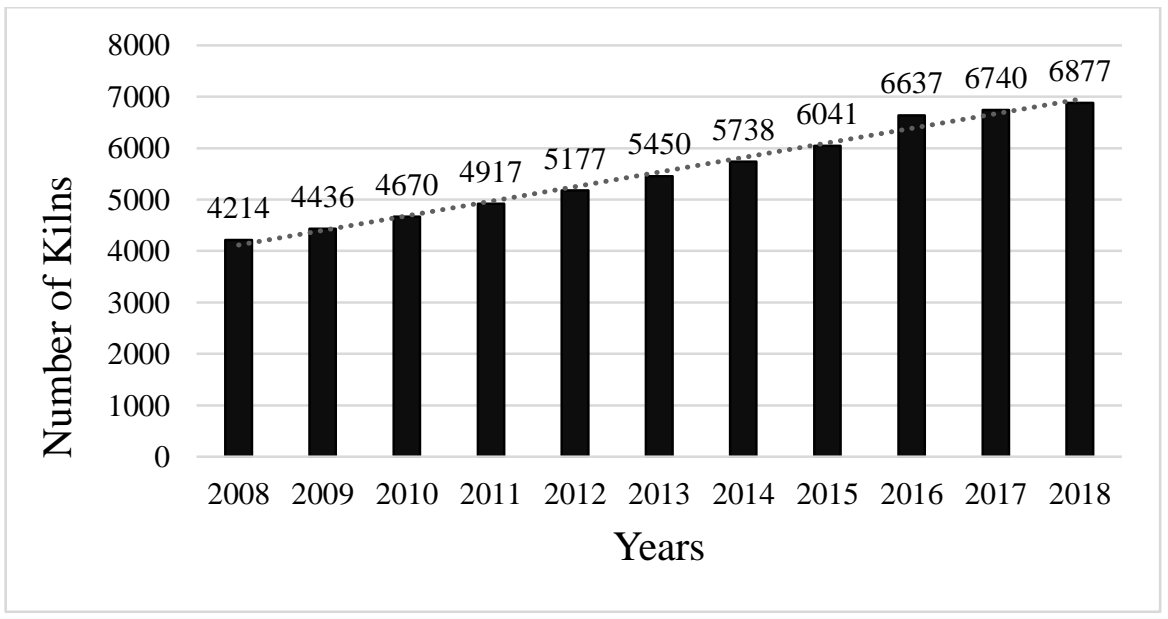

Fig 3. Total number of brick kilns in Bangladesh from 2008 to 2018. 
Figure 4 shows the Air quality index (AQI) of Dhaka air from 2014 to 2017 [26]. Range between 51-100 is considered moderate and between 151-200 in considered unhealthy condition. November- April is the burnt brick manufacturing season in Bangladesh. The AQI index is found higher beyond unhealthy range during that period. AQI is measured based on 5 criteria pollutants; Particulate Matter $\left(\mathrm{PM}_{10}\right.$ and $\left.\mathrm{PM}_{2.5}\right), \mathrm{NO}_{2}, \mathrm{CO}, \mathrm{SO}_{2}$ and Ozone $\left(\mathrm{O}_{3}\right)$.

\subsection{Impacts on land}

Brick kilns' are adversely impacting on land both quantitatively and qualitatively. So it is appearing as a threat to all sorts' of land use.

Quantitative impact on land: As per the existing rule of the government [12], a brick kiln cannot use more than two acres of land for its establishment. But in most cases this rule is being deliberately violated. Majority of brick kilns are found established on land previously used as agricultural land. So with the increase in number of brick kilns the cultivable land area is being shrinking rapidly.

Qualitative impact on land: The top 6 to 9 inches deep soil strata of agricultural land is the main and only preferred material, used for manufacturing the clay bricks. Topsoil contains silt, clay and sand and preserve nutrients for plant growth. There are various nutrients present in top soil, such as calcium, magnesium, boron, molybdenum, iron, manganese, nitrogen, phosphorus, potassium, sulpher, zinc, and chlorine etc. When from any arable land top soil is removed then the land losses its fertility to grow any crops or vegetation. So, the affected lands remain fallow for years together, affecting overall crop production. Soil formation is the great ecological concern as one inch thick of topsoil can take about 500 years to form naturally [27]. It takes more than five years to rejuvenate as arable land again by gaining fertility [27].

\subsection{Impacts on biodiversity}

According to various estimate, at least about 80 thousand $\mathrm{kg}$ of firewood are required at each brickfield a year [28]. As a result, trees are being destroyed and forest coverage is shrinking Accumulation of ashes, dusts on leaves interrupt photosynthesis; the way the trees generate food for themselves and thereby grow and survive. The fruit bearing trees in the vicinity of brick kilns do not give sufficient fruits in quantity, quality and size, as it would give before [29]. The hot fumes cause damage to the fruit and crop growing as because the tolerable temperature for the fruits and crops is about $30^{\circ} \mathrm{C}$. Due to the emission of hot fumes it causes slow burning of trees and ultimately die off. The effect on trees and crop lands due to the emission of brick kilns extended up to meters from the brick kilns. This causes damage to paddy and other greeneries around it [30].

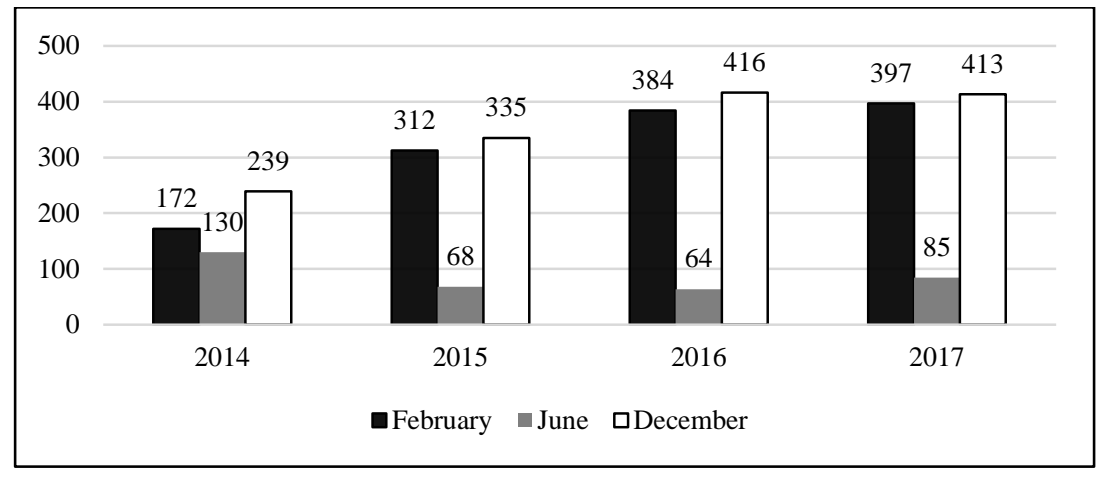

Fig 4. Air quality index (AQI) of Dhaka air from 2014 to 2017. 


\subsection{Impacts on public health}

As most of the brick kilns are situated near densely populated areas, many people are affected with respiratory diseases due to emission of toxic gases from the burning process carried in brick fields [31]. Children are the worst sufferers and most of them suffer from lungs disease [31]. Such pollution can cause lung cancer, partial loss of eye vision, various skin diseases and loss of diseaseresistance power. Especially the children and elderly people are often affected with various diseases, including bronchitis and asthma, due to environmental pollution, mostly due to burning of fossilfuel [31].

The carbon monoxide, present in the fume of brick kilns, reduces the oxygen content in the air, thereby causes breathing problem to the living beings. The elderly people and children are the worst sufferer. The children are caught by influenza and cold fever very often. It is feared that due to the incremental pollution of $40 \mu \mathrm{g} / \mathrm{m}^{3}$ due to the brick kilns in the north, might translates to an increase in more or less 5,000 premature deaths annually in the Dhaka city [32].

\subsection{Barriers in enforcement of laws and regulations}

The major barriers in enforcement of laws and regulations are briefly summarized below.

1. There are loopholes in the existing laws and policies. This is written in the Act 'The Brick Manufacturing and Brick Kilns Establishment (Control) Act 2013' [12] of our country that no individual will be permitted to utilize coal, as fuel, containing sulfur, mercury or comparative material, past the endorsed standard. But all coal, petroleum, and kerosene contain sulfur. Till now any standard or quality for coal has been set by the government.

This Act further states that, no person is allowed to use the soil as raw material in brick manufacturing, after cutting or collecting it from rural land or slope or hillock, without the endorsement of authority and can only cut or collect soil from dead pond, canal, swampland, rivers with the approval of appropriate authorities. But the law has not defined appropriate authorities and not prescribed the procedure. In addition, the Act restricts usage of small road in rural areas for transporting bricks which is totally unacceptable.

2. Majority of the brick field owners are politically and monetarily highly influential and very ignorant to the concern regulatory matters and the environmental consequences.

3. Poor governance of the concerned regulatory authorities in the context of licensing, renewal of license, monitoring and taking legal actions against the violators.

4. Absence of stringent rules and regulations in line of using alternative bricks in codes, construction rules etc.

5. Weakness of concerned law enforcing agencies and in industrial policy. It is observed that the existing industrial policy lacks in discouraging the entrepreneurs, addressing the environmental considerations, especially for setting up of heavy polluting industries like brick kilns.

\section{Results and discussions}

Potential perspective in adopting alternative bricks in Bangladesh

In public sector Housing and Building Research Institute (HBRI) has gone through various research works to find various alternatives of clay bricks [33].

\section{Thermal Block}

Thermal block is made of rich cementmortar casted around insulation material. Expanded polystyrene (EPS) is used as insulating material and to protect the EPS from external effect it is covered with sand-cement mortar. It has good heat resistance. A block size 
of 9.5 " 4.5 " 3 " weight around $1.5 \mathrm{~kg}$ only. It has a compressive strength of $4.5 \mathrm{MPa}$.

\section{Compressed Stabilized Earth Block (CSEB)}

Compressed stabilized earth block is made of dredged soil of rivers and Ordinary Portland Cement.

A block size of 9.5 " $\times 4.5 " \times 3 "$ weight around $3.5-4 \mathrm{~kg}$. It has a crushing strength of 5-6 MPa. It's water absorption capacity is $10-20 \%$.

Sand-Cement Hollow Block
It is made of sand and cement mortar. It has good heat resistance. A block size of 16 " $\mathrm{x} 4.5$ " $\mathrm{x} 8$ " weight around $2.5-3 \mathrm{~kg}$ only. It has a crushing strength of 5-6 MPa. It's water absorption capacity is less than $10 \%$.

\section{Interlocking CSEB}

Interlocking CSEB is made of dredged soil of rivers and Ordinary Portland Cement. No mortar needed for cementing blocks. A block size of 12 " $\times 5$ " $\times 4$ " weight around $7.5 \mathrm{~kg}$. It has a crushing strength of 7-8 MPa. It's water absorption capacity is less than $10 \%$.

Table 2. A comparative analysis between clay bricks and alternative bricks [34]

\begin{tabular}{|c|c|c|}
\hline Particulars & Clay Bricks & Alternative Bricks \\
\hline Size (in) & $9.5 " \times 4.5 " \times 2.75$ & $\begin{array}{l}16 " x 4.5 \text { "x } 8 \text { " (size can be } \\
\text { customized) }\end{array}$ \\
\hline Area $\left(\mathrm{in}^{2}\right)$ & $9.5 " \times 2.75 "=26$ & $16 " x 8 "=128$ \\
\hline Comparison & \multicolumn{2}{|c|}{$\mathrm{ABs}$ in 5 times larger than clay bricks } \\
\hline Speed of construction & Comparatively slower & $\begin{array}{l}\text { Comparatively faster due to bigger } \\
\text { size, light weight, less joints and } \\
\text { less thickness of plaster }\end{array}$ \\
\hline Material composition & $\begin{array}{l}\text { Clay (alumina), sand, lime, iron } \\
\text { oxide and magnesia etc. }\end{array}$ & $\begin{array}{l}\text { Sand, cement, crushed stone, } \\
\text { admixtures etc. }\end{array}$ \\
\hline Source of raw materials & Agricultural lands, hills etc. & $\begin{array}{l}\text { River dredged soil, construction } \\
\text { waste etc. }\end{array}$ \\
\hline Weight (per unit) & $3-3.5 \mathrm{Kg}$ & $\begin{array}{l}\text { Vary by size but lower than clay } \\
\text { brick }\end{array}$ \\
\hline Dry density & $1800-2000 \mathrm{~kg} / \mathrm{m}^{3}$ & $600-800 \mathrm{~kg} / \mathrm{m}^{3}$ \\
\hline Compressive strength & 2.5-3 MPa & 3-4 Mpa (can be customized) \\
\hline Water absorption & $15-20 \%$ & Less than $10 \%$ \\
\hline Efflorescence & Present & Absent \\
\hline Thermal conductivity & High & Lower than burnt bricks \\
\hline Fire resistance & Low & High \\
\hline Workability & Low & High \\
\hline \multicolumn{3}{|c|}{ Efficiency in use and production } \\
\hline 1. Mortar consumption & High & Low \\
\hline 2. Water usage & High & $\begin{array}{l}\text { Lower than burnt brick during } \\
\text { production period }\end{array}$ \\
\hline 3. Breakage & High during transportation & Low during transportation \\
\hline Earth quake resistant & Average & Good \\
\hline
\end{tabular}




\begin{tabular}{|c|c|c|}
\hline \multirow[t]{3}{*}{ Environmental impact } & $\begin{array}{l}\text { 1. Reduces the top fertile soil (one } \\
\text { clay brick consumes about } 3.2 \mathrm{~kg} \\
\text { of top soil) }\end{array}$ & 1. No agricultural topsoil needed \\
\hline & $\begin{array}{l}\text { 2. One sqft of carpet area with clay } \\
\text { bricks emit } 17.6 \mathrm{~kg} \text { of } \mathrm{CO}_{2}\end{array}$ & $\begin{array}{l}\text { 2. One sqft of carpet area with } \\
\text { alternative bricks emit } 2.2 \mathrm{~kg} \text { of } \\
\mathrm{CO}_{2}\end{array}$ \\
\hline & $\begin{array}{l}\text { 3. One sqft of carpet area with clay } \\
\text { bricks consume } 8 \mathrm{~kg} \text { of coal }\end{array}$ & $\begin{array}{l}\text { 3. One sqft of carpet area with } \\
\text { alternative bricks consume } 1 \mathrm{~kg} \text { of } \\
\text { coal }\end{array}$ \\
\hline Cost benefit & None & Dead load reduction \\
\hline \multicolumn{3}{|l|}{ Cost } \\
\hline 1. Labor cost & High & Low \\
\hline 2. Maintenance cost & High & Low \\
\hline 3. Unit price & $.0011 \mathrm{USD} / \mathrm{in}^{3}$ & $.00071 \mathrm{USD} / \mathrm{in}^{3}$ \\
\hline Applicability & Load bearing and Non-load bearing & $\begin{array}{l}\text { 1. Load bearing up to } 2 \text { to } 3 \text { story. } \\
\text { 2. Partition walls }\end{array}$ \\
\hline \multirow[t]{4}{*}{ Social impact } & 1. Unorganized Sector & 1. Organized Sector \\
\hline & 2. Child labor rampant & 2. Statutory labor \\
\hline & $\begin{array}{l}\text { 3. Unhealthy working condition } \\
\text { due to toxic gases }\end{array}$ & $\begin{array}{l}\text { 3. Healthy working condition, less } \\
\text { pollution }\end{array}$ \\
\hline & $\begin{array}{l}\text { 4. Very unsafe working } \\
\text { environment }\end{array}$ & $\begin{array}{l}\text { 4. Standardized factory facility } \\
\text { with automated process }\end{array}$ \\
\hline
\end{tabular}

Table 3. The comparison between a brick kiln (Zigzag Kiln) and a medium scale Sand Cement Hollow Block Plant

\begin{tabular}{|c|c|c|}
\hline Particulars & Brick kiln ( Zigzag kiln) & Sand Cement Hollow Block Plant \\
\hline Initial principal & 4 million BDT & 3.2 million $\mathrm{BDT}$ \\
\hline Land required & 10200 meter square & 205 meter square \\
\hline Raw materials & $\begin{array}{l}\text { Clay, sand, lime, iron oxide and } \\
\text { magnesia etc. }\end{array}$ & $\begin{array}{l}\text { Sand, cement, crushed stone, } \\
\text { admixtures etc. }\end{array}$ \\
\hline Labor & 200 person & $\begin{array}{l}\text { 20person (Ten times less than brick } \\
\text { kiln) }\end{array}$ \\
\hline Work Environment & Very unhealthy & Healthy \\
\hline Fuel Type & Coal & Electricity, oil \\
\hline Burning of wood/Coal & 20-24 ton per year & Require only to produce cement \\
\hline Loss of Topsoil & 95,000 cubic feet per year & 0 \\
\hline $\begin{array}{l}\text { Emission of } \mathrm{CO}_{2}, \mathrm{PM}, \mathrm{BC}, \mathrm{SO}_{2} \text {, } \\
\mathrm{NO}_{\mathrm{x}}, \mathrm{CO}\end{array}$ & High & Low \\
\hline Production period & November- April & Throughout All Year \\
\hline Production rate & 2.5 million bricks per year & $\begin{array}{l}2.7 \text { million blocks per year for } \\
\text { medium scale industry }\end{array}$ \\
\hline Wastage & $5-8 \%$ & $2-3 \%$ \\
\hline
\end{tabular}




\section{Provisions of $A B s$ in Bangladesh National Building Code (BNBC)}

In BNBC '93 or BNBC 2006, Chapter 2 of Part 5 provides guideline on building materials. BNBC has endorsed use of alternative materials which make provision of using alternative bricks. In Section 2.1.1, this is mentioned as "The provisions of this part are not intended to prevent the use of any new and alternative materials. Any such material may be approved provided it is shown to be satisfactory for the purpose intended and at least the equivalent of that required in this part in quality, strength, effectiveness, fire resistiveness, durability, safety, maintenance and compatibility."

In section 2.2.4 standard for various masonry units have been mentioned where concrete masonry unit and Sand-Lime unit is included. The standards are as below.

a) Concrete: Concrete masonry must comply with the following ASTM standard specifications- C90, C129, C145, C55, C73-75.

\section{Provisions in purchase schedules of Government authorities}

Public Works Department (PWD) is the leading department in public construction sector which implements building projects of various ministries of the Government of Bangladesh. PWD prepares a schedule of rates (SoR), time to time, for various items of works. In these items of works, the materials to be used in the item of works, are mentioned. At present SoR 2014 is being followed. In this SoR no concrete solid blocks are included but concrete hollow blocks of various sizes are included for both load bearing and non-load bearing walls [35].

Local Government Engineering Department (LGED) is another public development authority working for infrastructural development mostly in rural areas but also works in urban areas. Recently this department has included "Concrete hollow blocks" in building works in its latest schedule of rates (SoR) 2017. In the previous SoRs, the use of this item found missing.
Review of Policy, laws and regulations with respect to use of $A B$ 's

With respect to limiting use of clay bricks and introducing alternative bricks, majority of relevant national policies are found most favorable. National Environmental policy 2013 categorically emphasized that no industry would be allowed to pollute the surrounding environment. National Industrial policy 2016, in its section 14 of environment friendly industrial management, there is policy to establish industries not posing adverse effect on land, water and air. National Agriculture Policy 1999, in its section 12 of land use, it is categorically mentioned that non-agricultural use of fertile agricultural land will be stopped. National land use policy-2001, in its section 17, strongly supports stopping of conversion of agricultural land into non-agricultural purposes without prior permission from concern authority and proposes establishment of industries in designated industrial zone not on agricultural land. It can be worth mentioning that the related policies are all in favour of discouraging establishment of clay brick manufacturing kilns.

Examples of switching from clay bricks to ABs in other countries

There are ample examples of switching from use of clay bricks to alternative bricks in various parts of the globe.

In India the Central Pollution Control Board (CPCB) and the National Green Tribunal (NGT), among others, are in the process of formulating complete ban of using clay burnt bricks. Red clay bricks are completely banned in some areas of India, like Gurgaon of Haryana state. The National Green Tribunal of India has banned digging of earth across the country for making bricks and roads without prior environment clearance (EC)[36]. In Vietnam the Government issued a decision in 2000 to ban the traditional brickmaking production inside the urban perimeter within 2005. (Decision No 15/2000/QD-BXD, dated 24 July 
2000 of the Ministry of Construction), and it will take full effect in the entire country by 2017 [37]. In China the city government began banning the use of clay bricks in 1998 and all local brick-making plants were ordered to phase out production of solid shale bricks by 2001 . All the provincial capitals were decided to stop the use of clay bricks by the end of 2005 [38].

\section{Recommendations}

1. The corresponding authority must set standard or quality for coal used in brick kilns.

2. Appropriate authorities must be prescribed who will give approval and monitor the collection of soil from dead pond, canal, swampland, rivers for brick production.

3. The regulations are not clear and there are lots of loopholes in the existing law. So we need to develop new policy/regulation or guideline to make clear the existing law.

4. Appropriate regulatory authority is needed for controlled production of clay bricks and controlled use of clay bricks in building development.

5. Strong governance of the concerned regulatory authorities in the context of licensing, renewal of license, monitoring and taking legal actions against the violators.

6. Use of clay bricks must be reduced and use of alternative bricks must be increased. Use of clay bricks must be banned in areas where alternative bricks can fulfill the structural, aesthetic and environmental requirements.

7. Creating awareness for giving appropriate value of alternative bricks, as proposed earlier, will help reintroducing $\mathrm{ABs}$ in building construction. Study must be carried out for figuring out the existing acts or regulations in this perspective. If sufficient regulatory acts or laws are not existing, then necessary steps are to be taken in this regard.

8. Government sector must play important and leading role in reintroducing alternative bricks. Private sector can also play role by abiding rules and regulations and being concern about degradation of environment as part of their corporate, social and humanitarian responsibility. Potential manufacturers of clay bricks can take role by transforming their clay brick production into production of various alternating bricks, in phases, and switching ultimately into production of alternative bricks.

9. Government sector can take various activities through its various development authorities, to promote wider use of alternative bricks in building development industries. Government can use alternative bricks in Government projects to aware people and also to promote alternative bricks.

10. Sufficient initiatives shall have to be taken for research in finding various sustainable alternative bricks, using locally available material. Also sufficient training for masons.

11. Alternative bricks are to be made available at every corner of the country.

\section{Conclusion}

Clay bricks are found to be the only bricks being used in the construction industry. Number of brick manufacturing kilns is growing fast keeping pace with the growth of demand. Top soil of agricultural land is the main source of raw material for these bricks. Agricultural land is being degraded, environment is getting polluted and public health is under threat due to the proliferation of the brick kilns. There are various alternatives clay bricks. Alternative bricks did not get its right value in our construction industry. There are many reasons behind the non-acceptance of new alternative bricks. Nevertheless, use of alternative bricks has become the need of time now. Government sector is one of the potential development partners. In reintroducing alternative bricks the development authorities in government sector must play their vital role in this regard. Necessary rules and regulations are to be promulgated and administered strongly through establishing effective regulatory authority. An 
exclusive independent Building Regulatory Authority is to be established, as prescribed by the national building code to ensure use of alternative bricks according to the National building code and respective construction rules.

\section{Acknowledgments}

The study was done as a part of a project titled "Promoting Sustainable Building in Bangladesh". It is an initiative to promote alternative bricks in Bangladesh; a project funded by EU SWITCH Asia Programme, implemented by Oxfam in Bangladesh, Housing and Building Research Institute, Bangladesh Environmental Lawyers Association and Jagoroni Chakro Foundation. The authors would like to acknowledge the kind co-operation provided by the staffs of every project partners.

\section{References}

[1] S. Khan, Topsoil grabbing by brick kilns, The Financial Express, Dhaka, 2018.

[2] D. Biswas, E. S. Gurley, S. Rutherford and S. P. Luby, The Drivers and Impacts of Selling Soil for Brick Making in Bangladesh, Environmental Management, vol. 62, no. 4, pp. 792-802, 2018.

[3] "Pollution the killer," The Daily Star, Dhaka, 2018.

[4] A. Siddique, Alternative bricks: A boon for agriculture, Dhaka Tribune, Dhaka, 2016.

[5] UNDP, Eco-friendly brick technique helps build a cleaner Bangladesh, 2011.

[6] A. Ahmed, J. Sturges, Materials science in construction: an introduction, New York: Routledge, 2015.

[7] M. Ragavi, M. Sushmithaswarna, K. Mahendran, A Comparative Study On Various Building Blocks As An Alternative To Conventional Bricks, SSRG International Journal of Civil Engineering. (2017) pp. 774-783.

[8] Brick Industry Association (BIA), Specifications for and Classification of Brick, Virginia, 2017.

[9] B.M. Skinder, A.K. Pandit, A.Q. Sheikh, B.A. Ganai, Brick kilns: Cause of Atmospheric Pollution, J Pollut Eff Cont. 2(2) (2014).

[10] D. Lalchandani, S. Maithel, Towards Cleaner Brick Kilns in India, A win-win approach based on Zigzag firing technology', Ministry of Environment and Forests, (MoEF), India, 2009.

[11] O. Akinshipe and G. Kornelius , Chemical and Thermodynamic Processes in Clay Brick Firing Technologies and Associated Atmospheric Emissions Metrics-A Review, J. Pollut. Eff. Cont., vol. 5, no. 2, 2017.

[12] The Bangladesh Gazette, The Brick Manufacturing and Brick Kilns Establishment (Control) Act, 2013, Dhaka: Government of Bangladesh, 2013.

[13] C. Poon, S. Kou and L. Lam, Use of recycled aggregates in molded concrete bricks and blocks, Construction and Building Materials, vol. 16, no. 5 (2002) pp. 281-289.

[14] M. G. Subash, V. Satyannarayana and J. Srinivas, Aerated autoclaved concrete (aac) blocks: A revolution building material in construction industry, International Journal of Science Technology and Management. 5(1) (2016) 167-174.

[15] C. Bhanagale, Civil Engineering Materials, Ahmedabad, 2014.

[16] Project on alternative bricks inaugurated, The Independent, Dhaka, 2016.

[17] Dhaka air among the worst, The Daily Star, Dhaka, 2018.

[18] M.A. Rouf, M. Nasiruddin, A.M.S. Hossain and M. S. Islam, "Trend of Particulate Matter PM 2.5 and PM 10 in Dhaka City," Bangladesh J. Sci. Ind. Res. 46 (3)(2011) pp. 389-398.

[19] T.S. Adhikary, Green brick shows hope, The Daily Star, Dhaka, 2017.

[20] S. Guttikunda, "Impact Analysis of Brick Kilns on the Air Quality in Dhaka, Bangladesh," Sim-air, Dhaka, 2009.

[21] B.A. Begum, P.K. Hopke, Ambient Air Quality in Dhaka Bangladesh over Two Decades: Impacts of Policy on Air Quality, Aerosol and Air Quality Research, 18 (2018) 1910-1920 .

[22] United Nations Developement Programme , Improving Kiln Efficiency In The Brick Making Industry.

[23] Department of Environment , Annual Report, Ministry of Environment, forest and Climate Change, Dhaka, 2015- 2016.

[24] Department of Environment, Annual Report, Ministry of Environment, Forest and Climate Change, Dhaka, 2016-2017 .

[25] Department of Environment, Annual Report, Ministry of Environment, Forest and Climate Change, Dhaka, 2017-2018 . 
[26] S.A. Shams, Dhaka air pollution: Facts, measures and commandments, The Daily Star, Dhaka, 2017.

[27] S.D. Roy, P. Roy, PRECIOUS TOPSOIL burnt for bricks, The Daily Star, Lalmonirhat, 2016.

[28] "Brick kilns burn firewood, destroying CHT forest," The Daily Star, Khagrachhari, 2011.

[29] S. Hossain, Firewood-based brick kilns pose threat to environment, The Daily Star, Patuakhali, 2015.

[30] Crack down on kilns near farmlands and habitation, The daily Star, Faridpur, 2018.

[31] M.F. Jerin, S.K. Mondol, B.C. Sarker, R.H. Rimi, S. Aktar, Impacts of Brick Fields on Environment and Social Economy at Bagatipara, Natore, Bangladesh, J. Environ. Sci. \& Natural Resources. 9(2)(2016) 31-34.

[32] S. Shams, M.H. Rahman, J.N. Sahu, CFD Analysis of Brick Klin Flue Gases and its Health
Impact: A Case Study of Northern Part of Dhaka, Bangladesh, IUT Journal of Engineering and Technology (JET), vol. 12, no. 1, pp. 33-40, 2015.

[33] Special Report 2018, Housing and Building Research Institute, Dhaka, 2018.

[34] R. Shukla , Burnt Clay Bricks Versus Autoclaved Aerated Concrete Blocks, International Journal of Engineering Research \& Technology. 3(11)(2014) 575-580.

[35] Schedule of Rates for Civil Works (14th edition), Public Works Department (PWD) Bangladesh, Dhaka, 2014.

[36] Green tribunal bans digging earth for making bricks, roads, The Times of India, New Delhi, 2013.

[37] Review of Vietnam policy on brick kiln, New Delhi, 2015.

[38] Ban on Clay Bricks to Save Land, The China Daily, 2004. 